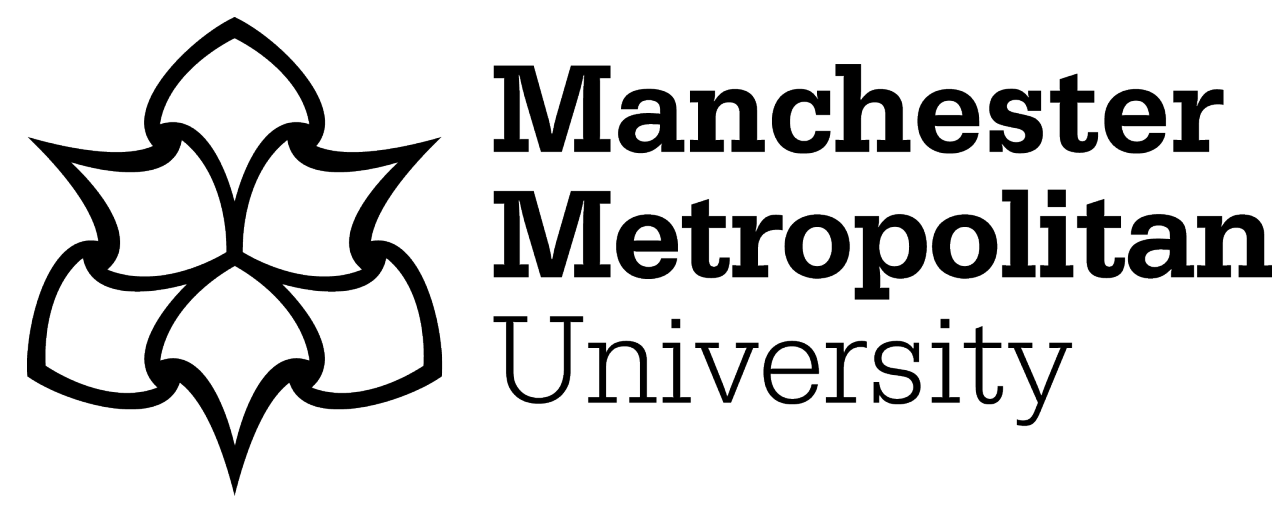

Young, C and Light, D (2015) Toponymy as commodity: exploring the economic dimensions of urban place names. International Journal of Urban and Regional Research, 39 (3). pp. 435-450. ISSN 0309-1317

Downloaded from: https://e-space.mmu.ac.uk/338022/

Version: Accepted Version

Publisher: Wiley

DOI: https://doi.org/10.1111/1468-2427.12153

Please cite the published version 


\title{
Toponymy as Commodity: Exploring the Economic Dimensions of Urban Place Names
}

\begin{abstract}
In recent years the study of urban toponymy (place names) has been revitalised by the emergence of a 'critical toponymies' approach. This focuses on the cultural politics of place naming and the decisions involved in attributing names to the urban landscape. However, in contemporary cities place names have an economic role in addition to their political role. In particular, there have been recent calls for more attention to the commodification of place naming rights and practices. This paper seeks to respond to these calls by addressing the issue of urban place names as commodities. It begins by examining the naming of sports stadia by corporate sponsors. It then considers a range of ways in which private sector interests are increasingly influencing the naming of the urban landscape, ranging from buildings, neighbourhoods and individual streets. Even the material signage that identifies street names can be appropriated within branding and promotional strategies. Moreover, urban place names are increasingly incorporated into a range of commercially-produced spatial data sets collated by private companies. The paper ends by proposing a number of directions for future research into the economic role of urban place names and the commodification of toponymy more broadly.
\end{abstract}




\section{Toponymy as Commodity: Exploring the Economic Dimensions of Urban Place Names}

\section{[A] Introduction}

Over the past decade scholars have directed renewed critical attention to place names. This literature focuses not on the origins and etymology of place names, but instead on the cultural politics of naming itself (Alderman and Inwood, 2013). It examines the decisions involved when attributing (or not attributing) a name to a place and the agendas of those who oversee or sponsor this process. In particular, places names are treated as being implicated in broader issues of power, identity, memory and culture. Thus, there has been considerable critical attention to the practices of "toponymic inscription" (Rose-Redwood et al., 2010) within the urban environment. Urban toponymy is treated as an important element of larger cultural landscapes that are produced in support of a particular political agenda, but which can also be contested by the denizens of the city itself.

In this article we seek to make a further critical intervention in this literature and to expand the research agenda on critical toponymies. In particular, we contribute to an emerging research debate about toponymy as commodity (see Rose-Redwood et al., 2010; Rose-Redwood 2011; Rose-Redwood and Alderman, 2011). Through engagement with related literatures and discussion of a range of illustrative examples we lay out a series of critical points which link recent developments focusing on the cultural and political aspects of place naming with a range of economic processes to explore the role of place names in the contemporary economic reshaping of urban worlds. The article begins with a review of the critical toponymies literature to establish the wider context and outlines its (so far brief) consideration of the commodification of place names. It then explores issues surrounding the commodification of urban place names in two main ways. First, the increasing privatisation and commercialisation of naming-rights to particular urban places and, second, the commercial use of place names in products using geographic information in new technologies and virtual space and reactions to it.

\section{[A] Critical Toponymies and the Contemporary City}

The study of toponymy has a long tradition in disciplines such as history, landscape history and historical geography, but until recently it has occupied a rather marginalized position within urban geography and urban studies (Rose-Redwood et al., 2010). Previously place names were interpreted as clues to the imprints of past cultures upon the landscape and for understanding the chronology of 
settlement history (Kearns and Berg, 2002; Vuolteenaho and Berg, 2009). This tradition was dominated by a focus on names themselves - particularly their derivations and origins - and an encyclopaedic emphasis on collecting and cataloguing place names. Little attention was paid, however, to the practice of naming itself (Rose-Redwood et al., 2010) and this approach treated toponyms in an atheoretical and apolitical manner (Vuolteenaho and Berg, 2009).

However, in recent years there has been a significant reorientation of research into place names led by an approach termed "critical toponymies" (Berg and Vuolteenaho, 2009; Rose-Redwood et al., 2010). This approach treats naming as a political practice and is underpinned by a recognition that "naming a place is always a socially embedded act, one that involves power relations" (Vuolteenaho and Berg, 2009: 9). The names attributed to places (settlements, urban streets, and landmarks) are not accidental or politically neutral, but are chosen and foregrounded as being somehow 'appropriate', while other, less acceptable, names are overlooked or marginalised. An important argument within this literature (and one that links to broader literatures emphasizing the links between landscape, performance, power and identity) is that attributing names to places is a way of embedding a particular set of political values into the urban landscape (Azaryahu, 1996, 2009).

This critical approach has done much to bring the study of place names into disciplines concerned with the relationships between urban space, power and identity. Within critical place name studies there are several key foci. One approach focuses on the role of naming urban places within practices of modern governmentality (Rose-Redwood, 2009; Vuolteenahu and Berg, 2009; Rose-Redwood et al., 2010). The naming of streets and roads (along with the numbering of housing) reflects a modernist desire for a rational and ordered urban space (Rose-Redwood, 2009) in which the location of each part of the city can be precisely identified and differentiated. Such a 'geo-locational regime' is necessary for the city authorities to identify, tax and police their populations and provide them with services (Rose-Redwood et al., 2010). In this context, naming urban places is one strategy through which urban space is rendered governable (Vuolteenaho and Berg, 2009) thereby facilitating broader processes of capital accumulation.

Another theme links to a broader inter-disciplinary agenda which focuses on memory and commemoration. This examines the role of attributing commemorative names (named in remembrance of key individuals or historical events) in the construction of collective memories. In this context naming is one element of strategies among elites to construct and institutionalize a hegemonic narrative of history. As Azaryahu (1996, 2009, 2011) argues, attributing a commemorative name to an urban street involves introducing an authorized version of history into the most banal and everyday of settings. In this sense, place names (along with other technologies such as statues and monuments) contribute to the construction of memorial arenas within the urban landscape (Alderman, 
2002). A further prominent theme within critical place name studies is renaming the urban landscape during times of radical political change so that it is concordant with the political aspirations and agenda of the incoming regime. A number of recent studies have examined this process of "toponymic cleansing" (Azaryahu, 2011: 29) in contexts such as post-colonialism (e.g. Whelan, 2003); post-socialism (e.g. Gill, 2005) and South Africa after apartheid (e.g. Swart, 2008).

While the study of toponymy has been reanimated by the emergence of critical place name studies, much recent work has tended to be rather narrowly focussed on the contested politics of place-naming (Rose-Redwood et al., 2010). There are, however, other important themes that deserve fuller attention (Rose-Redwood and Alderman, 2011). In this paper, we seek to develop this research agenda by focusing on the economic dimensions of naming practices and linking these to the wider sociocultural and political contexts of urban change. A great deal of recent work has traced the neoliberalization of urban political economies (Harvey, 1989; Hackworth, 2007; Theodore et al., 2011). Faced with economic downturn and de-industrialisation in the latter half of the twentieth century (and the economic pressures that have intensified since the global recession of 2008-9), cities around the world have increasingly embraced an 'entrepreneurial' agenda (Harvey, 1989). Cities have engaged in processes of inter-urban competition for national and international flows of state investment, capital, businesses, consumers and tourists. The development of entrepreneurial strategies has involved a strong emphasis on projects to reshape the image and identity of cities. Place marketing and branding, staging sporting and cultural mega-events, developing tourism and consumption, constructing flagship buildings and gentrifying urban cores are closely associated with attempts to change meanings associated with place and to counter perceptions of economic depression, stagnation, crime and urban decay.

Naming practices play an important role in these processes. Place names can represent a form of symbolic capital, in that they are associated with prestige and distinction and are valued for this reason (Rose-Redwood, 2008; Alderman, 2008). Such symbolic capital can be appropriated within place branding and promotion strategies in order to create distinctive place identities (Alderman, 2008; Alderman et al., 2012; Shoval, 2013). In this process, the symbolic capital of particular place names is converted (at least in part) to economic capital; that is, it becomes a resource to be sold. Moreover, there is growing evidence that the urban landscape is named in a way to link to generic tropes of capitalism and economic success or to specific corporate interests. This also maps onto an entrepreneurial agenda emphasizing public-private partnerships as new forms of urban governance in which the business and corporate world have an increasing influence. For urban authorities facing severe cut-backs in state expenditure, the naming rights to the urban landscape are rapidly growing in importance as potential economic resources. As Rose-Redwood (2011: 36) argues, "By turning public places into branded 'destinations', such public-private partnerships serve to legitimate corporate 
power and have the potential to reconfigure toponymic systems in cities around the world into new 'spaces of capital' (Harvey, 2001)".

Thus it is clear, to follow Rose-Redwood's assertion, that one "of the major transformations that will likely reshape the toponymic landscape of the next century is the commercialisation of public placenaming systems" (2011: 34). As the economic value of place names is the subject of increased attention by urban authorities and corporate interests, there is growing tension between the use-value of place names and their exchange-value (Rose-Redwood et al., 2010; Rose-Redwood and Alderman, 2011). The commodification of place names has resulted in an intertwining of the symbolic and economic capital that inheres in them. As Rose-Redwood and Alderman (2011:2) note, "the symbolic capital associated with a name has become so inextricably bound up with the economic logic of capital accumulation that the symbolic naming of a 'place' is itself increasingly being enlisted as an integral strategy of maximizing profitability" (and see Burton, 2008).

These processes feed into wider debates about the fate of public space and the public domain in the neoliberal city. As the political-economy of cities shifts towards the privatization of publicly-owned resources, including the public domain of naming rights, concerns have been raised about the threat of a "wholesale commercialization of public space" (Rose-Redwood and Alderman, 2011: 3) that "poses serious risks to the very notion of public space as a site of social life beyond the commercialized world of corporate culture" (Rose-Redwood et al., 2010: 466). Indeed, Rose-Redwood (2011: 35-6) suggests that we are witnessing "a significant extension of the corporate powers of "immersive" marketing in reshaping the publically-sanctioned, official toponymic landscape". As Berg (2011: 13) has argued, "neoliberalization is caught up in specific forms of naming that symbolically and materially solidify current (and historical) processes of capitalist accumulation by dispossession." The naming of places in ways that naturalize current forms of socio-economic and political organization in the landscape has implications for democratic accountability, public life and space, and forms of resistance to a hegemonic order. A major gap in research knowledge, however, concerns the experience and feelings of urban citizens about such naming processes, which may be exclusionary in quite mundane ways (Berg, 2011) but may also be ignored or the subject of apathy.

The commodification of place-naming rights in the neoliberal city is emerging as a significant research agenda within critical toponymies (Rose-Redwood, 2011) although this debate is still in its early stages. In this paper we seek to both develop and broaden this discussion by examining the commodification of urban place names in a variety of contexts. We begin by considering the increasingly common practice of selling the naming rights of sports stadia and arenas to corporate interests. The discussion provides important examples of the potential financial value of such sell-offs and raises issues for public-sector practice. We then examine a variety of situations which illustrate 
the growing involvement of private-sector interests in urban place names and practices of naming. The paper then examines the broader issue of how geographic data about the urban environment - of which place names are one element - is being commercialized and privatized, and considers reactions and alternatives to this commercialisation. The conclusion points to key issues in the development of a research agenda around the issue of toponymy as commodity in shaping contemporary urban worlds.

\section{[A] Toponymic Commodification I: The Privatisation of Naming Rights}

In this section we expand upon the points raised above about the increasing commodification of place names through the selling of naming rights. After reviewing the growing involvement of the private sector in the naming of sports stadia, we explore the involvement of the private sector more broadly in the naming of urban places. The discussion draws out issues around the ways in which the private sector is attempting to shape the everyday through its control of public space in a context where resource-limited urban authorities search for new corporate models.

\section{[B] Selling naming rights within the private sector: Renaming sports stadia}

The involvement of the private sector in naming sport stadia and cultural arenas is well established (Burton, 2008) and is frequently cited in the critical toponymies literature as a key illustration of the commodification of toponymy (Rose-Redwood et al., 2010; Rose-Redwood and Alderman, 2011; Rose-Redwood, 2011). However, with a few exceptions (Boyd, 2000; Vuolteenaho and Kolamo, 2012; Church and Penny, 2013) there has been limited scrutiny of this phenomenon. However, other disciplines such as sports marketing/sponsorship have evaluated its progress and impact as a marketing device (see for example Crompton and Howard, 2003; McCarthy and Irwin, 2000; Hollis, 2008) or discussed the legal dimensions of naming rights deals (see Drennan, 2011; Allen, 2011; Blocher, 2007).

English Premier League (EPL) soccer provides several illustrative examples where the naming rights to stadia have been sold as part of sponsorship deals. Writing in 2003, Crompton and Howard noted that although naming sport stadia after private sponsors had long been common in the USA, it was a new phenomenon in British soccer (which, itself, highlights the issue of the different national contexts in which toponymic commodification occurs). However, this has changed rapidly, mirroring the increasing drive to commercialize soccer clubs and maximize revenue streams (Giulianotti, 2011; Vuolteenaho and Kolamo, 2012; Church and Penny, 2013). Many clubs in the EPL have been subject 
to takeovers by overseas capital, linked to immensely valuable media deals. Now Vuolteenaho and Kolamo (2012: 145) talk of:

“...the mutation of English football into a fully-fledged, globally marketed branch of a spectacle-producing entertainment industry...a substantial share of major English soccerscapes have been lately (re-)textualised as "landscape advertisements" in their own right via naming right deals."

There are many examples. Bolton Athletic Football Club (FC), in the north of England, named their new stadium the Reebok Stadium (after their sponsors, sports shoe manufacturers) as early as 1997. It was subsequently renamed the JJB Stadium (sports clothing and accessories) and is currently the $D W$ Sports Fitness Stadium. Swansea FC play at the Liberty Stadium (property developers) and Stoke FC at the Britannia Stadium (banking and insurance). Arsenal FC named their London stadium the Emirates Stadium in 2006, sponsored by Emirates Airlines in a $£ 100 \mathrm{~m}$ deal with a further $£ 150 \mathrm{~m}$ deal agreed from 2012. Importantly, in some cases these naming rights deals have developed from straightforward sponsorships of soccer grounds to become part of complex and lucrative investments with, in some cases, significant implications for the development and re-imaging of urban areas. For example, Manchester City FC took over the stadium built for the 2002 Commonwealth Games which, under the direction of Manchester City Council, had been built in a highly depressed area of northeast Manchester as part of a broader sports-led regeneration strategy. Manchester City FC renegotiated its lease with the City Council in 2010, gaining the naming rights in exchange for a larger rental payment. In 2011 Etihad Airways became the main club sponsor and the stadium was renamed the Etihad Stadium. The ten-year sponsorship deal will bring $£ 400$ million of investment to the former industrial area with development of the club's youth academy, training and other facilities. Similarly, in 2013 Manchester United sold the naming rights to its Carrington training ground and training kit in a $£ 120 \mathrm{~m}$ ten-year deal with Aon insurance group.

These examples raise a range of broader issues regarding the sale of naming rights to the urban landscape. First, the financial returns for sales of naming rights to stadia are large in the corporate world but very large in terms of local authority budgets. As such, there is a strong case for cashstrapped local authorities to explore the auctioning of naming rights to the corporate sector. Of course, sports teams in major leagues with global media coverage have more to offer investors than urban authorities with building, street or transit stop names to auction. However, the selling of naming rights can go beyond just generating investment (as for example in selling sports teams' shirt sponsorships) to be a part of the efforts by city authorities to regenerate depressed areas of cities and to change their image nationally and internationally. 
Second, despite the significant commercialisation of English soccer, the example of sports stadia (in the UK at least) illustrates the need to manage the tension between capitalising on the exchange value of a name and recognising the significance of its use value for particular stakeholders (particularly fans). Clubs may have become "hyper-commodified" sporting venues (Vuolteenaho and Kolamo, 2012: 146) but they owe their existence to their fan bases and, even if those fan bases are becoming ever more international, English soccer clubs continue to be culturally embedded in local communities (something which often dates back to the late nineteenth-century). As such the names of stadia can be very meaningful forms of symbolic capital for fans, with associations of prestige, esteem and distinction that are rooted in particular local traditions and memories. Renaming a stadium to incorporate the name of a commercial sponsor may generate revenue for the club but can powerfully disenfranchise fans. As such it can be identified as an example of what Bourdieu (1991) terms symbolic violence (see also Alderman, 2008). As such, practices of naming can contribute to reproducing social inequalities and the exclusion of particular groups and stakeholders (RoseRedwood et al. 2010; Alderman and Inwood, 2013).

Indeed, in the UK the renaming of sport stadia is often contentious (and perhaps for this reason only five out of twenty-two stadia have adopted the name of commercial sponsors). Some clubs which have moved to new stadia have had to engage in campaigns to gain acceptance for the new name among fans (see Edensor and Millington (2008) on Manchester City FC and Church and Penny (2013) on Arsenal). Renaming stadia as a part of massive corporate sponsorship and brand awareness strategies raises questions about the commercialisation of elements of the urban landscape which are often deeply embedded in everyday practices and imaginations (Edensor and Millington, 2010; Church and Penny, 2013). Whatever official name is adopted for corporate ends does not necessarily determine the everyday use of names by fans, who can often circumvent the name promoted by corporate sponsors and retain 'traditional' names because of their historical significance and place in the rituals of supporting their team.

Indeed, there are several high-profile cases of popular opposition to the renaming of a sport stadium. These illustrate 'symbolic resistance' to naming practices, something that is a prominent theme in the critical toponymies literature (Azaryahu, 1996; Alderman, 2008; Vuolteenaho and Berg, 2009; RoseRedwood et al., 2010). For example, Newcastle United FC's stadium was originally named St James' Park. However, in 2011 the club adopted Sports Direct Arena (after a sport clothing company). This resulted in considerable protest by fans, some of which included grafittiing of the original name. In 2012 a new corporate sponsor reinstated the original name stating that it was responding to the wishes of fans. When Southampton FC moved to a new stadium in 2001 it originally had a hybrid name of The Friends Provident St. Marys Stadium. The Friends Provident element came from the sponsoring insurance company but it was pressure from fans that led to the incorporation of St. Marys into the 
name (in reference to the club's 1885 origins). In 2006 the club's new sponsors declined to purchase the naming rights and the name reverted to St. Mary's. The renaming of stadia can be such an explosive issue that many of the biggest EPL clubs (such as Manchester United or Liverpool) have avoided any attempt to invite corporate sponsorship of their stadia names since they are well aware that to do so would result in huge protest among fans.

To date, however, there has been little academic examination of popular opposition to the renaming of sport stadia. Indeed, little is known more broadly about how renaming practices are absorbed, consumed or resisted by fans (Edensor and Millington, 2010; Church and Penny, 2013). However, as Boyd (2000) suggests, there is a danger that corporate naming of sports venues and other parts of the urban landscape presents a growing threat to public memory of places of many kinds. These issues around the corporate commodification of naming are also relevant to potential research into the commercialisation of naming in the public sphere. Businesses such as soccer clubs have to manage the tension inherent in exploiting the commercial potential of a name which raises important questions for public-sector authorities attempting to do the same.

[B] Selling naming rights within the public sector: Naming, corporate branding and the creation of economic landscapes

The example of sports arenas demonstrates the growing influence (and financial significance) of the private sector in naming urban places. We now consider the growing intersection of private-sector involvement with broader practices of naming the public urban landscape. Entrepreneurial forms of urban governance increasingly draw on private sector models and seek to forge new public-private partnerships. In this context the value of naming rights realized by private companies has not gone unnoticed by urban authorities (for example, in the USA school boards and university authorities have sold the naming rights to school and university buildings (Burton 2008; Drennan 2011; Blocher 2007). We examine these issues with reference to naming transport infrastructure, urban neighbourhoods and individual streets within the city.

To begin with we acknowledge that the influence of private capital on the naming of the urban landscape has clear historical antecedents. Cities contain many examples of street names which reflect their original economic function. Before the nineteenth century, for example, many urban streets in countries such as the United Kingdom (UK) bore generic names related to their principal economic and commercial activities (eg. Bread Street). The former eighteenth and nineteenth century industrial core of north Manchester (UK) is still marked by names such as Brewer Street, Tariff Street, Gun Street, Loom Street, Cable Street, Iron Street, Old Mill Street, and Silk Street, while other street names 
- Empire Street, Bengal Street, Canada Street - reference broader economic networks of trade, political-economic (capitalist and Imperialist) power and trans-national connections. In addition, some street names have long been metonymic for particular economic activities such as Wall Street in New York. Others - such as Carnaby Street in London - have long associations with fashion, youth subcultures and consumption. It is worth noting that naming streets to reflect a broader economic agenda was not restricted to capitalist societies. State-socialist regimes throughout Eastern Europe and Soviet Union also frequently named streets in ways reflecting economic priorities and aspirations. For example, in socialist Romania (1947-89) streets in the capital, Bucharest, were named Street of Production, Street of Labour, Street of Progress, and Agricultural Reform Street (Light, 2004).

There is undoubtedly scope for further historical studies which examine how the urban landscape was named to reflect the dominant economic order. However, we suggest that the economic dimension of naming urban places is becoming more significant due to contemporary shifts in the politicaleconomy of cities and the development of new forms of public-private sector collaboration. The example of naming sports stadia has not been lost on cash-starved public authorities. As part of the neoliberalization of urban space such authorities are increasingly selling or auctioning naming rights to corporate sponsors, with public transport a particular focus (Rose-Redwood, 2011; Rose-Redwood and Alderman, 2011). This offers the potential for a city authority to generate revenue to support public transportation whilst enabling corporate interests to engage in major branding exercises. In various US cities mass-transit authorities have renamed subway stations after corporate sponsors. In Las Vegas station and train naming rights have been sold, and in Tampa, Florida the same has happened to an entire public transport line (the TECO Line Streetcar System, named after a utilities company). In New York, one subway station was renamed Atlantic Avenue Pacific Street-Barclays Center Station as part of a US\$4 million sponsorship agreement with Barclays Bank, which also sponsors a sports stadium near the stop. Philadelphia's subway boasts an $A T \& T$ stop. Elsewhere, Rose-Redwood (2011) details the selling off of station names on the Dubai Metro, while in the context of the marketization of societies during post-socialist transformation other examples can be found, such as in Budapest, Hungary where Ferenc Körút (Ferenc Boulevard) subway station was renamed Corvin Negyed (Corvin Quarter) after a nearby real estate development.

Another issue concerns local authorities renaming entire areas or urban neighbourhoods as part of urban regeneration projects. The private sector has a growing role in this practice since the governance of regeneration is more frequently managed by public-private organisations. For example, the New Manchester Development Company has renamed a large area of north and east Manchester as East Manchester, a name which is alien to the communities who live in the area. Parts of Ancoats, a former industrial working-class community, have been renamed New Islington (a name which does pick up on a former name in the area) and Little Italy (referring to a smaller area with an Italianate 
church which historically was the focus of Manchester's Italian community). Here new names have been devised to address negative perceptions of the area and to contribute to city marketing and branding strategies. A further example was the renaming of London's former East End docks area as London Docklands, a name now synonymous with the international financial services sector, but which at the time alienated local residents (Burgess and Wood, 1988). This again illustrates how the commodification of place names can be contested. A name that represents valuable symbolic capital for one group (in this case developers and investors) can represent symbolic violence for another group (local people) (Bourdieu, 1991; Alderman, 2008).

The involvement of the private sector and the growth of various forms of public-private partnership and collaboration in the practice of (re-)naming streets is a growing phenomenon. One good example of the complexity of such arrangements is provided by Hungary ${ }^{1}$ which, in fact, has a long history of naming streets after commercial enterprises. For example, Budapest has streets named after Tungsram, a successful Hungarian light and vacuum tube manufacturer established in 1896 (now a subsidiary of General Electric), and a square named after Ikarus, the bus manufacturer which traces its origins back to 1895 . However, this phenomenon has become more common with the marketization of the economy following the end of state-socialism in 1989 and there are contemporary examples of naming streets directly after commercial enterprises. These reveal a diversity of relationships between the companies and the geographical scales at which meanings are created by the naming process. For example, Campona Str. (Budapest) and Auchan Str. (Törökbálint) are named after nearby shopping malls and are a part of embedding and promoting these retail developments in the urban landscape. There are a number of examples where streets have been named after Hungarian companies, which is in part about reflecting the importance of these locations in the new capitalist economy: Gyál has Fundy Str. (a Hungarian candy producing company); Gógánfa (a small village in the Western region) has Rockwool Str. (the company produces rock wool); Ráckeve has Nowaco Str. (a food processing company); and Üllö has $K$-Sped Boulevard (K-Sped is a transport company).

A further set of street names reflect the significance of international investment for the Hungarian economy, and the naming practice is clearly linked with promoting Hungary as being firmly embedded in global capitalist economic networks. These include the new Mercedes factory at Kecskemét which is located on Mercedes Str.; Nokia Str. in Komárom (a town on the HungarianSlovakian border which has a Nokia factory); and Samsung Square in Jászfényszaru (Samsung has a television factory there). In some cases commercial names are linked with historical figures, which integrates street naming with wider processes of place promotion and also establishing new discourses of the nation-state after socialism. One example is Hertz Str. in Vecsés, a town near Budapest Airport. This is named after the Hungarian franchise Hertz Mercur Rent a Car, and links to the fact that the original founder of the company was born in Hungary. According to the company webpage the name 
is intended as an homage to the creativity and commitment of Hungarians generally. Clearly, in this case the street name is linked to a globally-known company to promote both essentialized notions of Hungarian character that chime with the ethos of capitalism (and a rejection of stereotypes of socialism) and to support the re-establishment of Hungary as part of European and global economies.

These examples also reveal a complex set of relationships between local government and the private sector. In some cases the companies involved built new roads which they named after themselves, while in other instances businesses paid local authorities for the naming rights. There are also examples where urban administrations chose to name streets after the companies without payment, perhaps as a means of establishing good relations with them, and in order to embed them (and the investment and employment that they bring) into the local economy.

Another area of commercial practice which illustrates the intertwining of the cultural and economic capital associated with a name is the complex link between an address and house prices. It is well established that particular addresses can represent a valuable form of symbolic capital (RoseRedwood 2008) that confers distinction and status upon the occupant. This, in turn, inflates land values and house prices as the street become a fashionable and desirable place to live. This phenomenon has long been noted by key urban actors such as estate agents, whose discursive and representational practices link particular streets and neighbourhoods to ideas of 'luxury inscription' (Rofe, 2003). It is common practice for estate agents to purposefully boost property prices by associating properties and streets with particular areas in cities, which often become more-and-more 'stretched' as realtors seek to shift the boundaries of desirable areas as far as possible. This relationship between street name and property prices is also quantified and commodified by inclusion in hedonic pricing models which are used in economic decision-making by real estate agents and property developers. The hedonic pricing method incorporates a number of factors to model how the value of a property is affected by quantitative and qualitative characteristics, including neighbourhood variables such as perceptions of an area of a city as particularly desirable. This can also be a factor in locational-decision making by businesses, with some companies seeking to link the quality and competency of their services with a prestige street name (such as the association between Harley Street in London and private medical practitioners).

Conversely, other addresses can be associated with a negative place image so that they are regarded as undesirable places in which to live or locate a business. Such place names are, therefore, characterised by an absence of both symbolic and economic capital (at least for some social groups). Such reputations may be unmerited but nevertheless the perception that an address is in an area with a poor reputation can significantly influence attitudes towards such places. Mitchelson et al. (2007) examined this issue with reference to streets in the USA named after the Rev. Martin Luther King. 
They note that, because such streets are frequently imagined as being located in areas dominated by the African-American community, they are stereotyped as being associated with deprivation, crime and economic marginalisation and disadvantage (see also Alderman and Inwood, 2013). This negative 'branding' in turn, influences consumer behaviour and investment decisions, and is the root of opposition (by both individuals and businesses) to proposals to rename existing streets (throughout the country) after King. In fact, through a sophisticated analysis, the authors demonstrate that, at a national level, streets named after King were not more likely to be associated with economic marginality or disadvantage.

In addition to the debates surrounding the commodification of a name itself, there are further issues regarding the materiality of the physical signage that is used to label and identify urban streets. It is becoming increasingly common for urban administrations to brand certain quarters of cities and use them in city marketing to attract tourists and consumers. While this involves the physical regeneration of these areas it is also important to address the look and feel of a quarter to support marketed images and meanings. Street name labels can be a core part of this process. The historic centre of Bucharest (Romania) is a good illustration. This area has recently undergone extensive regeneration by a publicprivate partnership and is now a lively urban quarter with many shops, bars and restaurants in preserved buildings. Part of the theming of this area as the 'historic centre' includes the installation of new street name signage which is clearly differentiated from that used elsewhere in the city in terms of size and colour and which features a 'script' font that mimics old handwriting. The design of the street name plates mimic those of Paris, seeking to re-establish Bucharest's historical links to the West and its former image as 'Little Paris'. This clearly demarcates the historic centre as a distinct quarter of the city. In Manchester (UK), an area now branded as the Northern Quarter, associated with hipster-ism, creativity, fashion and music, has had very little public-sector regeneration, with changes and investment largely private-sector driven. However, the City Council has developed the Northern Quarter brand heavily in city marketing and has invested in introducing a standard, more artistic style of street nameplate (and see McCarthy, 2006). In Victoria, Gozo (Malta) urban regeneration of historic neighbourhoods such as Fontana involves introducing new 'historic' looking street nameplates.

In other instances temporary or mock street name signage can be installed as part of promotional, sponsorship or branding strategies by both private and public sector organisations. For example, in March 2009 a section of $53^{\text {rd }}$ Street in New York was renamed U2 Way (complete with temporary signage) for a week. This was intended to coincide with the release of a new album by the band and a week of performances in the city (Michaels, 2009). A similar development took place in Bucharest in 2007 when a series of imitation street name signs appeared in the city centre that directly imitated the style and colour of the 'official' signage. However, instead of containing street names these new signs 
contained mysterious statements such as "my street"; "the street where I played football with the boys"; and "the street where my grandmother lived". Eventually it became apparent that the new signage was part of a campaign entitled "Why we love Bucharest" sponsored by the private company responsible for the city's water supply. The campaign was intended to encourage Bucharesters to feel positive about their city but undoubtedly also included an element of promotion and brand management by the utility provider. What was significant was that the most everyday and seemingly banal of objects - street name signs - were appropriated as part of this project.

The renaming of urban landmarks to reflect commercial sponsorship can generate a wide range of responses among (and within) elites and publics (see Alderman and Inwood, 2012). While many urban authorities have chosen to sell or auction naming rights within the urban domain it is certainly not the case that local elites and decision-makers are invariably supportive of such initiatives. For example, in San Francisco the directors of the local public transport system voted against selling the naming rights to metro stations, indicating that the commercialisation of urban toponymy is not inevitable (Rose-Redwood, 2011). A good illustration of the plurality of responses to the involvement of the private sector in naming the urban landscape can be seen in London. In June 2013 the Conservative group on the Greater London Authority issued a report (Bacon, 2013) calling for an increase in the commercial sponsorship of the city's public transport network (particularly Underground stations) as a means to freeze or reduce fares. The report cited the increasing prevalence of this practice in other global cities and cited a poll where $74 \%$ of the London public supported expanding sponsorship on the public transport network. However, subsequent discussions on online fora appeared to indicate that many Londoners were far more ambivalent about the suggestion. The proposal was rejected by Transport for London (the local government body responsible for public transport in the capital) on the grounds of the costs of changing maps and signs (BBC News, 2013). The Conservative Mayor of London also appeared unconvinced by the proposal which, by autumn 2013, had not been taken forward.

\section{[A] Toponymic Commodification II: New Technologies, Mobilities and the Commercialisation of Urban Place Names}

While the analysis above is concerned with naming-practices another important area for research is the commercialisation of place names within a variety of products, along with the reactions to this commodification. In this section we consider the commodification of urban place names through their inclusion in products associated with urban mobility and the broader issue of the commercialisation of 
'public' data, processes which again begin to trace the tensions between the symbolic and economic value of place names.

Street names have a long history of being valued as commodities in a range of practices associated with moving through urban space. Many taxi drivers, for example, commit a thorough knowledge of street names to memory as part of their employment. Indeed in some cases - the "Knowledge" required by London Black Cab drivers being the best example - the ability to memorize the map of the city centre is necessary in order to gain a taxi license. Publishing companies have also long been involved in the commercial exploitation of street names, through selling them in the form of street maps or A-Z guides. A key issue here is that companies attempt to control knowledge of and the ability to represent street names through various forms of copyright and licensing. What exists in the public sphere, in the form of street names present on the roadside, also becomes a commodified, commercially restricted and privatized form of geographic representation. In recent years this commodification has been intensified through the development of new technologies such as personal 'sat-nav' (satellite-navigation) devices, some of which can be programmed to speak the names of streets to aid navigation. This is accompanied by the growth in sales of smartphones with GPS and talking map applications. Approximately 7.5 million sat-navs have been sold in the UK since 2004 . Moreover 722 million smartphones were shipped in 2012 and over 128 million tablet devices were sold in the same period (Lomas, 2013). Smartphones and other mobile devices are used for a variety of purposes as well as navigation, but sales of sat-navs have dropped over the last two years which industry sources attribute to the impact of this new technology and the various map and navigation apps that are available. Overall, however, these figures point to a huge commercial value for digital street name databases which can be incorporated into these new technologies. These, in turn, are rapidly being integrated into everyday spatial practices.

Another aspect of the commodification of urban place names has been the development of commercialized digital spatial data sets, often related to the commercial pressures which have grown on formerly state-owned mapping agencies which, again, has resulted in the privatization and copyrighting of such data. In the UK, for example, the Ordnance Survey (OS) has long sold paperbased maps but has moved into the area of developing and selling digital datasets. This is the result of funding pressures which have led to the need for agencies such as the OS to generate commercial revenue. From 1999 the OS has had to be self-funding from the commercial sale of datasets and products (leading to criticisms that this is incompatible with its role as a public supplier of geographic information). At the same time, there have been growing market demands for spatial datasets, which include place/street names. These include the increasing commercial use of spatial datasets in sectors such as utilities and retailing, but also growing demand from local and national government services, 
such as planning, policing and security. Again, new technology has been an important part of these changes, allowing the provision and/or sale of spatial data sets in digital form.

Here, again, urban street names are bound up into rapidly changing technologies in new areas of market demand with commercial opportunities. However, this also brings to the fore a new set of issues around the tensions inherent in the commercial control and exploitation of what might be regarded as 'public' data. Governments have made huge investments in developing digital datasets and this has involved the licensing and privatisation of public-sector data. Local governments, for example, have found themselves being charged to use data which was produced by the public sector in the first place. Other publically-funded users (notably university researchers, NGOs, and the nonprofit sector) also feel that this commercialisation has led to their exclusion from what should be publically available digital base data. In the UK these tensions have led to a growth in Open Data provision which refers to the need to make all kinds of publically-collected data available to the public under the 2010 Open Government Licence (similar to the Creative Commons licencing arrangements). The 2013 Shakespeare report (Shakespeare, 2013) argues that freeing up public data which it values at $£ 1.8$ billion but with a potential wider socio-economic value of $£ 6.8$ billion - is vital for driving economic growth in a supposedly creative and services based economy. Thus, in the UK the commodification of spatial data, which includes the names of urban streets, is taking place in the context of a broader debate about whether geographical information (GI) should be commercialized (and privatized) or be publically available.

These debates are still being worked through, but one response in the UK is that the government has made some compromises in the ongoing commodification of spatial data. The OS thus offers a suite of OpenData products, which it says will "increase innovation" and "support greater transparency and accountability within government and lead to better services for citizens. It will also enable businesses, communities and individuals to make greater use of GI, which will in turn benefit the UK economy" (http://www.ordnancesurvey.co.uk/oswebsite/support/os-opendata-general.html). Clearly, the intention is not to remove the economic aspect of spatial information, but to make it more freely available to release the indirect economic benefit of its use without restrictions, such as creating new businesses or making cost savings through more efficient operations. The OS thus now offers a range of online products including OS StreetView, OS VectorMap, OS MasterMap, which offer free and unrestricted access to boundary data and maps with some geographic features. Criticism continues, however, as some of the most profitable data products were not included, a point which is countered by the OS's argument that if they had to make everything freely available then it would cost the government $£ 30 \mathrm{~m}$ annually. Clearly these debates about the commodification of public data, including spatial data and urban street names, still have some way to go in the UK context. Moreover, 
this debate will be worked out differently in other national contexts, suggesting a research agenda into the contested social, political and economic aspects of this form of commercialisation of toponymies.

However, there is a reaction to the commercialization of ostensibly 'public' geographic data and the increasingly restricted access to such data. This movement seeks to make GI (including urban place names) freely available. A key example is 'OpenStreetMap'² (OSM) which was launched in 2004. Taking its inspiration from Wikipedia, OSM is a non-profit foundation which produces a constantly growing free, editable online map of the world built on open source software and licenced for any use under an Open Database License. The rationale for the project is that "most maps you think of as free actually have legal or technical restrictions on their use, holding back people from using them in creative, productive, or unexpected ways" (http://wiki.openstreetmap.org/wiki/Main_Page). Having been granted free use of base data by some corporations or state agencies, any member of the public can sign up and upload data using various software editors, creating crowdsourced or 'volunteered geographic information' (Goodchild, 2007). This data may be derived from local knowledge, or informal surveying with GPS whilst walking or cycling. OpenStreetMap has rapidly become a global phenomenon and the project currently records over $1.1 \mathrm{~m}$ contributors (http://wiki.openstreetmap.org/wiki/Main_Page). It is a further illustration of how elite projects to control the process of naming urban places - or in this case, restricting access to the data which contains those names - can be contested in a variety of ways.

Academic research on the issue has tended to focus on assessments of the technical accuracy of the resulting data (eg. Haklay, 2010; Neis et al., 2012). However, there is clearly an opportunity for further research into the issues raised by the commercialisation of public geographical data and the counter-trends of crowdsourcing data and making it free to all. In particular, the motives for participating in OpenStreetMap could be further explored since it could reveal a complex sociocultural and political geography of popular relationships with place and attachments to place names (and see Goodchild, 2007). This may include a resistance to the commercialisation of geographical data or at least a desire to participate in a non-commercial alternative.

\section{[A] Conclusion}

Within critical toponymy the economic role and exchange-value of urban place names have received little attention and this role remains under-theorized (Rose-Redwood, 2011). Recent papers (RoseRedwood et al., 2010; Rose-Redwood and Alderman, 2011; Rose-Redwood, 2011) have highlighted the growing significance of the commodification of place-naming rights and have identified this as an 
issue which merits further research. In this paper we have sought to respond to these calls and to put more flesh onto the bones of the idea of 'toponymy as commodity'. In particular, we have identified a range of ways in which the private sector plays a growing role in the naming of the urban landscape, from transport interchanges, to entire neighbourhoods and individual streets. These developments can be clearly situated in the context of the neoliberalization of urban governance. As urban authorities are increasingly starved of resources they seek new sources of finance from the private sector and the sale of naming rights is one way of generating additional revenue.

Our discussion and analysis in this paper points to a number of directions for future research into the commodification of toponymy and its implications. First, while we concur with Rose-Redwood's (2011) claim that the commercialization of place-naming will bring about a major transformation of the urban landscape, we argue that there is a need for a much fuller understanding of how this takes place. In particular, there is a need for in-depth case studies of the commodification of urban placenaming rights. Such case studies could look at the practices of how city authorities and governing elites arrive at the decision to sell or auction their place naming rights. For example, are such decisions reached through necessity and the lack of any alternatives or, conversely, are city managers enthusiastic participants in the process? Similarly, are such decisions unanimous or is there internal disagreement? Moreover, the legal and institutional mechanisms through which place-naming rights are transferred to a private sponsor merit fuller examination. Another issue is the choice of sponsor. Is this decision simply based on which private company is willing to pay the most, or is preference given to particular interests? In particular, is there any evidence of preference for sponsors that have an existing or established connection with the city, or those that are likely to show some respect for the local symbolic capital that inheres in the existing toponymic landscape? These might seem like obvious issues but at this stage of the debate there is a need for more research into the details of how the commodification of urban place names actually unfolds.

A second issue that merits further research is the geography of toponymic commodification. To begin with, it is important to examine national variations in naming practices and responses. The issue of naming sports stadia discussed above serves as an illustration. The practice is far more common in the USA (Crompton and Howard, 2003) where sports fans are more accustomed to (and accommodating of) corporate naming of their stadia (though the renaming of stadia can provoke dissent). By contrast, even in the highly commodified English Premier League, the corporate naming of stadia is relatively uncommon. US soccer venues are generally much more recently constructed, often specifically for Major League Soccer, and thus are often corporately named at the time of construction or historically relatively recently. English soccer clubs can trace a much longer history where stadium names are more embedded in local history, memory and community and where fan bases are less willing to accept a corporate appropriation of their symbolic capital. This would also vary between different 
sports with different histories and commercial structures, and in different national contexts. An important question is thus whether citizens in different countries would respond differently to the corporate renaming of public space? Moreover, further research could examine if there is a policy mobility element to toponymic commodification. In particular there is an opportunity to examine if such commodification is (as is sometimes held) more of a North American phenomenon which is spreading throughout the world? The examples of street names in Hungary cited above, where there is a longer history of commodifying urban street names, would challenge such a simplistic picture of policy transfer from the English-speaking world to other contexts. Further research could examine different national practices of naming and whether these are examples of policy mobility from one context to another.

Third, there is considerable scope to consider the implications of the commercialization and privatization of the naming of urban places for the residents of the city who are most directly affected. Place names can be very significant for grounding local senses of place, identity, belonging and memory. However, where urban place names are changed to reflect the interests of a private sponsor the disappearance of familiar toponymic landmarks can destabilise long-established habits and routines and embedded attachments to place (and associated senses of identity and memory). As such, renaming urban places can be an unsettling experience for ordinary people in the city. This, in turn, raises broader issues regarding social justice, itself another important research agenda within critical toponymic studies (Rose-Redwood et al., 2010). As Alderman and Inwood (2013) argue, naming represents a means of taking ownership of places and this practice inevitably excludes or marginalises particular social groups. Moreover they argue that the commodification of urban naming rights is "an important infringement on the right of ordinary people to participate in the production of space" (224). The renaming of urban places to reflect private interests potentially disenfranchises ordinary urban residents and denies them a voice in naming the environment in which they live. The increasing commodification of place naming rights is, therefore, something that might disenfranchise certain groups of residents within a city whilst further empowering corporate interests. In this sense, the commercialization of place naming can reproduce and exacerbate existing inequalities and social divisions within the neoliberal city.

However, there is a need for detailed examination of how urban dwellers respond to, and negotiate, the commodification and renaming of familiar urban landmarks since little is known about this issue. For some the introduction of new names may indeed be an unsettling experience. Moreover, others may actively oppose and contest the renaming of urban places to reflect the interests of a corporate sponsor (in the way that fans have opposed the renaming of iconic football stadia). Certainly there is widespread recognition within the critical toponymies literature that top-down practices of (re)naming can be disputed and resisted by ordinary urban residents but we know little about how this is worked 
out. However, other responses may be much less purposeful and indeed renaming a public transport interchange, neighbourhood or street to reflect private sponsorship may have very little impact on the everyday lives and practices of the city's inhabitants. Many urban residents may pay relatively little attention to the toponymic landscape of their city and may accept the commercialisation of place naming as just another part of the mundane background to their everyday practices, habits and rhythms. Others may continue to use the former names simply out of habit.

In short, in order to better understand responses to the renaming of urban places we would echo Azaryahu's (2011) call for more attention to the users (or consumers) of (urban) place names and the significance of these names within practices of everyday life. A few recent studies (Shoval, 2013; Light and Young, forthcoming) have directly addressed this issue but there is considerable scope for further research which specifically focuses on responses to the renaming of the urban landscape. Certainly, a greater understanding of the uses and users of place names would better enable city authorities to manage the balance between the symbolic and economic capital that inhere in urban places names.

Finally, while the commodification of urban place naming rights is certainly the most visible aspect of the commodification of toponymy there are many other aspects of the exchange-value of place names that also merit investigation. In particular, the commodification of toponymy within popular culture, leisure and broader practices of consumption awaits fuller study. Place names are increasingly absorbed into a range of consumer products. These include board games such as 'Monopoly'; guides to local place names that are sold in many tourist destinations; reproduction street signage that is sold as tourist souvenirs in many major cities; and imitation street signage that is used to brand cafes, restaurants and a range of other businesses. Some places actively promote themselves on the basis of their place names (such as Vulcan in Canada), while others promote unusual or quirky microtoponyms (such as Whip-ma-Whop-ma Gate in York, UK). Therefore, 'mere' place names can be appropriated for a range of economic agendas by a broad range of actors. Having successfully reanimated the study of toponymy to put the politics of place naming centre stage, there is now an opportunity for critical place name studies to move the debate forward by giving the economic dimensions of toponymy (within their political context) equal critical attention. 
1 The authors are deeply indebted to Dr. Lajos Boros of the Department of Social and Economic Geography, Faculty of Science and Informatics, University of Szeged for supplying these examples.

${ }^{2}$ The authors are deeply indebted to Graham Smith of the School of Science and the Environment, Manchester Metropolitan University for discussions of OpenData and OpenStreetMap.

\section{References}

Alderman, D.H. (2002) Street names as memorial arenas: The reputational politics of commemorating Martin Luther King, Jr. in a Georgia county. Historical Geography 30, 99-120.

Alderman, D.H. (2008) Place, naming and the interpretation of cultural landscapes. In P. Howard and B.J. Graham (eds.) The Ashgate Research Companion to Heritage and Identity, Ashgate, Aldershot

Alderman, D.H., Benjamin, S.K. and P.P. Scheider (2012) Transforming Mount Airy into Mayberry: Film-induced tourism as place-making. Southeastern Geographer 52.2, 212-39.

Alderman, D.H. and J. Inwood (2013) Street naming and the politics of belonging: spatial injustices in the toponymic commemoration of Martin Luther King Jr. Social and Cultural Geography 14.2, 211-33.

Allen, G.W. (2011) Negotiating, drafting and implementing naming rights agreements. North Dakota Law Review 86, 789-812.

Azaryahu, M. (1996) The power of commemorative street names. Environment and Planning D: Society and Space 14.3, 311-30.

Azaryahu, M. (2009) Naming the past: the significance of commemorative street names. In L. Berg and J. Vuolteenaho (eds.), Critical Toponymies: The Contested Politics of Place Naming, Ashgate, Farnham.

Azaryahu, M. (2011) The critical turn and beyond: the case of commemorative street naming. ACME: An International E-Journal for Critical Geographies 10.1, 28-33.

Bacon, G. (2013) Untapped resource: Bearing down on fares through sponsorship. London: Greater London Authority Conservatives.[WWW Document]. http://glaconservatives.co.uk/wpcontent/uploads/2013/05/Untapped-Resource.pdf. (accessed 8 September 2013).

BBC News (2013) Tube lines could be sponsored to freeze fares, say Tories. 3 June 2013. [WWW Document].http://www.bbc.co.uk/news/uk-england-london-22745677 (accessed 8 September 2013).

Berg, L. (2011) Banal naming, neoliberalism, and landscapes of dispossession. ACME: An International E-Journal for Critical Geographies 10.1, 13-22.

Berg, L. and J. Vuolteenaho (eds.) (2009) Critical Toponymies: The Contested Politics of Place Naming, Ashgate, Farnham.

Blocher, J. (2007) School Naming Rights and the First Amendment's Perfect Storm. The Georgetown Law Review 96.1, 1-57. 
Bourdieu, P. (1991) Language and Symbolic Power (edited by J.B. Thompson), Harvard University Press, Cambridge.

Boyd, J. (2000) Selling home: corporate stadium names and the destruction of commemoration. Journal of Applied Communication Research 28.4, 330-46.

Burgess, J. and P. Wood (1988) Decoding Docklands: Place advertising and decision-making strategies of the small firm. In J.D. Eyles and D.M. Smith (eds.), Qualitative Methods in Human Geography, Policy, Cambridge.

Burton, T. (2008) Naming Rights. Legacy Gifts and Corporate Money, Wiley, Hoboken, NJ.

Church, A. and S. Penny (2013) Power, space and the new stadium: the example of Arsenal Football Club. Sport in Society 16.6, 819-34.

Crompton, J. and D. Howard (2003) The American experience with facility naming rights: opportunities for English professional football teams. Managing Leisure 8.4, 212-26.

Drennan, W.A. (2011) Where generosity and pride abide: charitable naming rights. University of Cincinnati Law Review 80.1, 58-111.

Edensor, T. and S. Millington (2008) 'This is our city': Branding football and local embeddedness. Global Networks 8.2, 172-193.

Edensor, T. and S. Millington (2010) Going to the match: the transformation of the match-day routine at Manchester City FC. In S. Frank and S. Steets (eds.) Stadiumworlds. Football, space and the built environment, Routledge, Abingdon.

Gill, G. (2005) Changing symbols: The renovation of Moscow place names. The Russian Review 64.3, 480-503.

Giulianotti, R. (2011) Sport Mega Events, Urban Football Carnivals and Securitised Commodification: The Case of the English Premier League. Urban Studies 48.15, 3293-3310.

Goodchild, M.F. (2007) Citizens as sensors: the world of volunteered geography. GeoJournal 69.4, 211-21.

Hackworth, J. (2007) The Neoliberal City: Governance, Ideology and Development in American Urbanism, Cornell University Press, Ithaca.

Haklay, M. (2010) How good is volunteered geographic information. A comparative study of OpenStreetMap and Ordnance Survey datasets. Environment and Planning B 37.4, 683-702.

Harvey, D. (1989) From managerialism to entrepreneurialism: The transformation in urban governance in late capitalism. Geografiska Annaler B 71.1, 3-17.

Harvey, D. (2001) Spaces of capital: Towards a critical geography, Routledge, New York.

Hollis, S. (2008) Stadium naming rights - a guided tour. Journal of Sponsorship 1.4, 388-94.

Kearns, R.A. and L.D. Berg (2002) Proclaiming place: Towards a geography of place name pronunciation. Social and Cultural Geography 3.3, 283-302. 
Light, D. (2004) Street names in Bucharest 1990-1997: Exploring the modern historical geographies of post-socialist change. Journal of Historical Geography 30.1, 154-172.

Light, D. and Young, C. (forthcoming) Habit, memory, and the persistence of socialist-era street names in post-socialist Bucharest, Romania. Annals of the Association of American Geographers.

Lomas, N. (2013) IDC: Tablet sales grew 78.4\% YoY in 2012 - expected to pass desktop sales in 2013, portable PCs in 2014. TechCrunch, 23 March 23 2013. [WWW document). URL http://techcrunch.com/2013/03/27/idc-tablet-growth-2012-2017/. (accessed 24 June 2013).

McCarthy, J. (2006) Regeneration of cultural quarters: public art for space or identity? Journal of Urban Design 11.2, 243-62.

McCarthy, L.M. and R. Irwin (2000) An examination of the rationale and motives for corporate purchase of stadia and arena naming rights. Cyber-Journal of Sport Marketing 4.3, 1-9.

Michaels, S. (2009) U2 Way: there the streets do have a name. The Guardian 4 March 2009. [WWW document]. URL http://www.guardian.co.uk/music/2009/mar/04/u2-new-york-street (accessed 19 June 2013).

Mitchenson, M.L, Alderman, D.H. and E.J. Popke (2007) Branded: The economic geographies of streets named in honor of Reverend Dr. Martin Luther King, Jr. Social Science Quarterly 88.1, 12045.

Neis, P., Zielstra, D. and A. Zipf (2012) The street network evolution of crowdsourced maps: OpenStreetMap in Germany 2007-2011. Future Internet 4.1, 1-21.

Rofe, M. (2003) 'I want to be global': theorizing the gentrifying class as an emergent elite global community. Urban Studies 40.12, 2511-26.

Rose-Redwood, R. (2008) From number to name: Symbolic capital, places of memory and the politics of street renaming in New York City. Social and Cultural Geography 9.4, 431-52.

Rose-Redwood, R. (2009) Indexing the great ledger of the community: Urban house numbering, city directories, and the production of spatial legibility. In L. Berg and J. Vuolteenaho (eds.) Critical Toponymies: The Contested Politics of Place Naming, Ashgate, Aldershot.

Rose-Redwood, R. (2011) Rethinking the agenda of political toponymy. ACME: An International EJournal for Critical Geographies 10.1, 34-41.

Rose-Redwood, R., Alderman, D. and M. Azaryahu (2010) Geographies of toponymic inscription: new directions in critical place-name studies. Progress in Human Geography 34.4, 453-70.

Rose-Redwood, R. and D. Alderman (2011) Critical interventions in political toponymy. ACME: $A n$ International E-Journal for Critical Geographies 10.1, 1-6.

Shakespeare, S. (2013) Shakespeare Review. An independent review of public sector information. UK Government Department for Business, Skills and Innovation. London. [WWW document]. URL https://www.gov.uk/government/uploads/system/uploads/attachment_data/file/198752/13-744shakespeare-review-of-public-sector-information.pdf (accessed 24 June 2013).

Shoval, N. (2013, in press) Street naming, tourism development and cultural conflict: the case of the Old City of Acre/Akkp/Akka. Transactions of the Institute of British Geographers. 
Swart, M. (2008) Name changes as symbolic reparation after transition: The examples of Germany and South Africa. German Law Journal 9.2, 105-20.

Theodore, N., Peck, J. and N. Brenner (2011) Neoliberal urbanism: Cities and the rule of markets. In G. Bridge and S. Watson (eds.) The New Blackwell Companion to the City, Blackwell, Oxford.

Vuolteenaho, J. and L.D. Berg (2009) Towards critical toponymies. In L.D. Berg and J. Vuolteenaho (eds.) Critical Toponymies: The Contested Politics of Place Naming, Ashgate, Aldershot.

Vuolteenaho, J. and S. Kolamo (2012) Textually produced landscape spectacles? A Debordian reading of Finnish namescapes and English soccerscapes. In J. Vuolteenaho, L. Ameel, A. Newby and M. Scott (eds.) Language, Space and Power: Urban Entanglements. Helsinki Collegium for Advanced Studies, Helsinki.

Whelan, Y. (2003) Reinventing Modern Dublin: Streetscape, Iconography and the Politics of Identity, University College Dublin Press, Dublin. 